\title{
The Role of Computed Tomography Findings in Prediction of Stone Composition
}

\section{Bilgisayarlı Tomografi Bulgularının Taş Kompozisyonunu Öngörmedeki Rolü}

\author{
Serdar Çelik', Canan Altay², Ozan Bozkurt ${ }^{3}$, Fatih Gülbey Kaya² ${ }^{2}$ Ömer Demir ${ }^{3}$, Mustafa Seçil ${ }^{2}$ \\ ${ }^{1}$ Gaziemir Nevvar Salih Işgören State Hospital, Clinic of Urology, İzmir, Turkiye \\ ${ }^{2}$ Dokuz Eylül University Faculty of Medicine, Department of Radiology, Izmir, Turkiye \\ ${ }^{3}$ Dokuz Eylül University Faculty of Medicine, Department of Urology, İzmir, Turkiye
}

\begin{abstract}
Hounsfield units (HU) provides a quantitative assessment of stone density in the urogenital tract on non-contrast computed tomography (NCCT) and has the ability to predict treatment success. The difference in HU (HUdiff) value was measured on NCCT in two patients. Our opinion is that HUdiff can predict stone composition before treatment.
\end{abstract}

Keywords: Hounsfield units, non-contrast computed tomography, stone composition, kidney stone, stone homogeneity/heterogeneity

\section{Öz}

Hounsfield ünitesi (HU), üriner sistem taş dansitesinin kontrastsız bilgisayarlı tomografi (NCCT) değerlendirmesinde kantitatif veri ile tedavi başarı oranlarını gösterme yeteneğine sahiptir. Bu yazıda, iki hastanın NCCT'sinde HU değerleri arasındaki fark (HUdiff) ölçülmüştür. Bize göre, HUdiff değeri tedavi öncesi taş kompozisyonunu öngörebilmektedir.

Anahtar Kelimeler: Hounsfield ünitesi, kontrastsız bilgisayarlı tomografi, taş kompozisyonu, böbrek taşı, taş homojenitesi/heterojenitesi

We evaluated two 18-year-old patients who presented to our clinic with flank pain. The patients underwent metabolic evaluation and non-contrast computed tomography (NCCT). In 24-hour urine analysis, patient-1 had high oxalate and low citrate levels, while patient-2 had a high homocysteine level. NCCT images revealed a renal stone in the right kidney in both patients. Stone diameters and Hounsfield units (HU) were measured with large magnification in bone window on NCCT images (Figure 1). The difference in HU (HUdiff) was calculated as the difference between maximum and minimum $\mathrm{HU}$ for estimated and predicted stone homogeneity/heterogeneity and stone composition. After percutaneous nephrolithotomy, stone analysis found a calcium oxalate ( $\mathrm{CaOX}$ ) stone in patient-1 and a cystine stone in patient-2.

In recent studies, HU values were evaluated on NCCT to detect a predictive cut-off value of mean $\mathrm{HU}$ for the prediction of treatment success $(1,2,3,4)$. In the studies, HU values and stone analysis were compared for the prediction of stone composition. The average mean HU was reported as 565-698 HU for cystine and 700-1438 HU for CaOX stones in different studies $(5,6,7,8)$. In current patients, the mean HU value, HUdiff value, standard deviation (SD) value and stone analysis were detected as 1445 HU, $592 \mathrm{HU}, 128 \mathrm{HU}$ and CaOX for patient-1 and $662 \mathrm{HU}, 236$ $\mathrm{HU}, 52 \mathrm{HU}$ and cystine for patient-2, respectively. In a recent study, stone heterogeneity index was described in ureteral stones by Lee et al. (9) and it was defined as the SD of HU on NCCT. They calculated minimum, maximum and SD of HU values on NCCT images. After the analysis, a strong relationship was found between a large SD of $\mathrm{HU}$ and stone heterogeneity in stone composition in their reports. In fact, our study supports this study. HUdiff provides similar indications to SD of HU value in recent and our studies. The SD of $\mathrm{HU}$ was calculated on

Correspondence: Serdar Çelik MD, Gaziemir Nevvar Salih İşören State Hospital, Clinic of Urology, İzmir, Turkiye

Phone: +902324123451 E-mail: serdarcelik84@hotmail.com

Received: 07.02.2017 Accepted: 02.03.2017

Cite this article as: Çelik S, Altay C, Bozkurt 0, Kaya FG, Demir Ö, Seçil M. The Role of Computed Tomography Findings in Prediction of Stone Composition. J Urol Surg 2017;4:91-93.

๑Copyright 2017 by the Association of Urological Surgery / Journal of Urological Surgery published by Galenos Publishing House. 


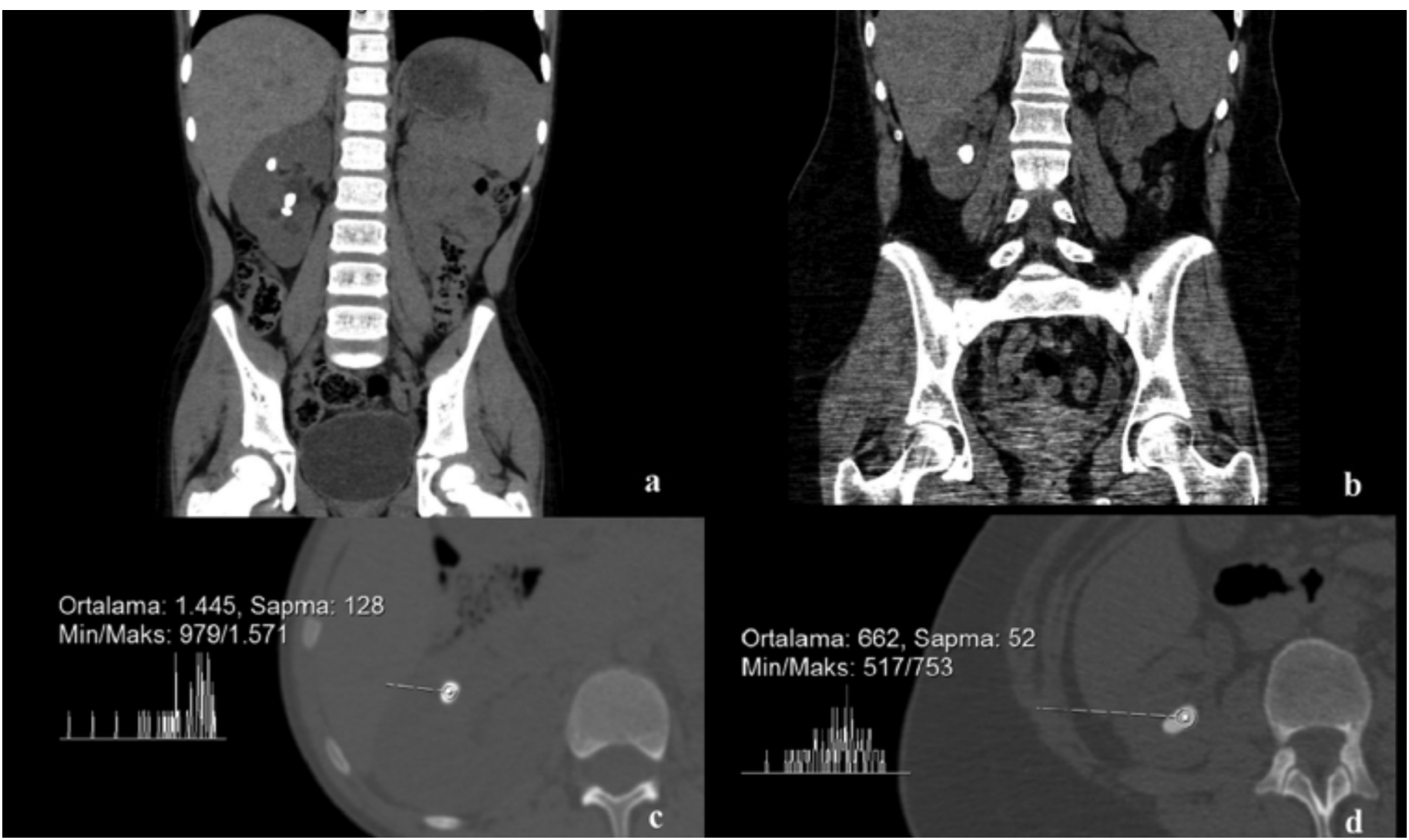

Figure 1. Kidney stones of patient-1 (a) and patient-2 (b) on coronal non-contrast computed tomography images. (c) The stone in the right kidney of patient-1; stone diameter (9.3 mm), maximum Hounsfield units (1571), minimum Hounsfield units (979), mean Hounsfield units (1445), standard deviation (128) and the difference in Hounsfield units (592) were calculated on axial non-contrast computed tomography image. (d) The stone in the right kidney of patient-2; stone diameter (11.6 mm), maximum Hounsfield units (753), minimum Hounsfield units (517), mean Hounsfield units (662), standard deviation (52) and the difference in Hounsfield units (236) were calculated on axial non-contrast computed tomography image

Min: Minimum, Max: Maximum, SD: Standard deviation

NCCT images, HUdiff was calculated as the difference between maximum and minimum $\mathrm{HU}$ measurements.

In conclusion, we found that HUdiff was correlated with stone heterogeneity and inversely correlated with stone homogeneity, similar to SD of HU value.

\section{Ethics}

Informed Consent: Consent form was filled out by all participants.

Peer-review: Externally peer-reviewed.

\section{Authorship Contributions}

Surgical and Medical Practices: S.Ç., O.B., Ö.D., Concept: S.Ç., C.A., Design: S.Ç., C.A., Data Collection or Processing: S.Ç., C.A., F.G.K., Analysis or Interpretation: S.Ç., C.A., O.B., Ö.D., M.S., Literature Search: S.Ç., C.A., O.B., Writing: S.Ç.

Conflict of Interest: No conflict of interest was declared by the authors.
Financial Disclosure: The authors declared that this study received no financial support.

\section{References}

1. Celik S, Bozkurt 0, Kaya FG, Egriboyun S, Demir O, Secil M, Celebi I. Evaluation of computed tomography findings for success prediction after extracorporeal shock wave lithotripsy for urinary tract stone disease. Int Urol Nephrol 2015;47:69-73.

2. Molina WR, Marchini GS, Pompeo A, Sehrt D, Kim FJ, Monga M Determinants of holmium:yttrium-aluminum-garnet laser time and energy during ureteroscopic laser lithotripsy. Urology 2014;83:738-744.

3. Ito $H$, Kawahara $T$, Terao $H$, Ogawa $T$, Yao $M$, Kubota $Y$, Matsuzaki J. Predictive value of attenuation coefficients measured as Hounsfield units on noncontrast computed tomography during flexible ureteroscopy with holmium laser lithotripsy: a single-center experience. J Endourol 2012;26:1125-1130.

4. Çelik S, Bozkurt O, Kaya FG, Karakoç S, Çelebi Çelik F, Demir Ö, Seçil M, Kefi A. Role of Computed Tomography Findings for Predicting Extracorporeal Shock Wave Lithotripsy Success in Children. Deu Med J 2015;29:71-77.

5. Kawahara $T$, Miyamoto $H_{\text {, Ito }} H_{\text {, Terao }} H_{\text {, Kakizoe }} M$, Kato $Y$, Ishiguro $H$, Uemura $H_{1}$ Yao $M$, Matsuzaki J. Predicting the mineral composition of 
ureteral stone using non-contrast computed tomography. Urolithiasis 2016;44:231-239.

6. Li X, Zhao R, Liu B, Yu Y. Gemstone spectral imaging dual-energy computed tomography: a novel technique to determine urinary stone composition. Urology 2013;81:727-730.

7. Stewart G, Johnson L, Ganesh H, Davenport D, Smelser W, Crispen P, Venkatesh R. Stone size limits the use of Hounsfield units for prediction of calcium oxalate stone composition. Urology 2015;85:292-295.
8. Spettel S, Shah P, Sekhar K, Herr A, White MD. Using Hounsfield unit measurement and urine parameters to predict uric acid stones. Urology 2013;82:22-26.

9. Lee JY, Kim JH, Kang DH, Chung DY, Lee DH, Do Jung H, Kwon JK, Cho KS. Stone heterogeneity index as the standard deviation of Hounsfield units: A novel predictor for shock-wave lithotripsy outcomes in ureter calculi. Sci Rep 2016;6:23988. 